UDK: 28:336.76]::122 Izvorni naučni rad

Mudžahid Štulanović, asistent

Univerzitet u Bihaću

Islamski pedagoški fakultet

mudzastulanovic@gmail.com

\title{
PRINCIPI I INSTRUMENTI ISLAMSKOG FINANSIJSKOG TRŽIŠTA
}

\section{Sažetak}

Finansijsko tržište (engl. financial market, njem. Finanzmarkt) ili tržišta novca u konvencionalnoj ekonomiji označava skup institucija $i$ transakcija gdje se susreću kupci i prodavači $i$ na kojima se odvija trgovina kapitalom, odnosno to su mjesta, osobe, instrumenti, tehnike i tokovi koji omogućavaju razmjenu novčanih viškova $i$ manjkova, tj. novca, kapitala $i$ deviza. Nerazvijena financijska tržišta su svedena na depozit, kredit i banke, a razvijena obiluju financijskim instrumentima, raznovrsnim financijskim institucijama, složenim financijskim tehnikama $i$ brojnim financijskim tokovima pa se dijele na tržište novca i kratkoročnih vrijednosnih papira, tržište kapitala i devizno tržište.

Postavlja se aktualno i važno pitanje da li i kako ovako definirano finansijsko tržište može funkcionirati u uvjetima isključivanja kamate i kamatarenja iz finansijskih operacija?

To je pitanje na koje moraju odgovoriti treoretičari islamske ekonomije koja ne priznaje kamatu kao dozvoljenu vrijednost. Pitanja islamskog financijskog tržišta spadaju u domen varijabilne islamske ekonomske prakse koja se razlikuje u vremenu i prostoru, podložna je promjeni i prilagodbi, ali isto tako moraju se uskladiti sa konstantnim, nepromjenljivim principima islamske ekonomije. Neki teoretičari islamske ekonomije, kao što je i sam Ahmed Osman Babikir, daju prijedlog kratkoročnih islamskih finansijskih instrumenata koji su zasnovani na murabehi, mušareki, mudarebi, baj'i alselem, istisna'u i idžari modelima finansiranja, a koji bi se mogli koristiti u operacijama na islamskom novčanom tržištu. 
Ključne riječi: Islamska ekonomija, islamsko finansijsko tržište, konvencionalna ekonomija, tržište novca, tržište kapitala, finansijski instrumenti, islamski finansijski instrumenti.

\section{Uvod}

Islamske financije i njihovo tržište u savremenoj islamskoj ekonomiji je njen posebno značajan segment iz razloga što islam najstrožije zabranjuje kamatu. Zbog toga je to jedno od najznačajnijih pitanja savremene islamske ekonomske misli koja se u nekim principima krucijalno razlikuje od konvencionalne ekonomije, a uprkos toga treba pronaći odgovarajuća rješenja za ovo savremeno pitanje u suglasju sa Šerijatom. Također, zbog činjenice da islamske banke ne posluju sa kamatom ni kod ponude niti potražnje, onda one ne mogu učestvovati na konvencionalnom novčanom tržištu koje je zasnovano na kamati i operacijama povezanim sa kamatom.

Prema tome, a usljed nerazvijenosti islamski prihvatljivog novčanog tržišta, njegovih instrumenata i institucija, islamske banke su u potrebi da razvijaju finansijske instrumente zasnovane na principima Šerijata.

$\mathrm{U}$ tom smislu smo u ovom radu obradili generalne principe islamske ekonomije, istraživali i definirali finansijska tržišta u konvencionalnoj ekonomiji, komparirajući ih sa tim principima a, onda, govorili o neprihvatljivim finansijskim instrumentima iz konvencionalne ekonomije koji nikako ne odgovaraju principima islamske ekonomije da bi iza toga, na osnovu svega, ukratko se osvrnuli na odgovarajuće instrumente za islamsko finansijsko tržište.

Koristili smo dostupnu stručnu literaturu na našem, arapskom i engleskom jeziku koristeći metodologiju islamske jurisprudencije, metodu deskripcije, navođenja, analize, dedukcije i indukcije tradicionalnih tekstova islama završavajući rad sa zključcima i registracijom literature i izvora spomenutih ili korištenih u obradi ove teme.

\section{Financijska tržišta u konvencionalnoj ekonomiji}

Iako se pitanja islamskog financijskog tržišta u primjeni islamske ekonomije krucijalno razlikuju od poimanja konvencionalne 
ekonomije, posebno zbog nepomirljivog stava islama sa kamatom i kamatarenjem, kojima je objavljen rat u islamskoj ekonomiji moramo, da definiramo finansijsko tržište i da ga onda odredimo i kompariramo principima jedne i druge ekonomske znanosti kako bi došli do rješenja o dozvoljenosti njegovih instrumenata ili nedozvoljenosti u islamskoj ekonomiji.

Jednostavnu definiciju spomenutog termina $u$ konvencionalnoj ekonomiji čitamo na Wikipediji gdje se navodi: da financijska tržišta (u širem smislu) ili tržišta novca označavaju skup institucija i transakcija gdje se susreću kupci i prodavači i na kojima se odvija trgovina kapitalom.

Dijeli se primjerice na:

\section{Tržište novca}

\section{Burze}

\section{Devizno tržište}

\section{Tržište osiguranja}

U Leksikonu - Poslovnom dnevniku nalazimo definiciju da je: Financijsko tržište (engl. financial market, njem. Finanzmarkt), mjesta, osobe, instrumenti, tehnike i tokovi koji omogućavaju razmjenu novčanih viškova i manjkova, tj. novca, kapitala i deviza. I dok su nerazvijena financijska tržišta svedena na depozit, kredit i banke, razvijena obiluju financijskim instrumentima, raznovrsnim financijskim institucijama, složenim financijskim tehnikama i brojnim financijskim tokovima, pa se dijele na tržište novca i kratkoročnih vrijednosnih papira, tržište kapitala i devizno tržište. Praktično postoji mnoštvo tržišta: dionica, obveznica, državnih vrijednosnih papira, kredita, opcijskih i futures tržišta, tržišta potraživanja po kreditnim karticama, leasinškim poslovima, izvoznim potraživanjima (tržište novca, tržište kapitala, primarno tržište, sekundarno tržište, burza, OTC tržište itd.).

Dakle, to je prostor na kojem se susreću ponuda i potražnja financijskih sredstava. Odnos koji se stvara između ponude i potražnje tih sredstava oblikuje njihovu tržišnu cijenu. Cijena se formira kamatom, a izražava kamatnom stopom. Kao i svako drugo tržište, financijsko je tržište konglomerat posebnih tipova poslova i institucija što se javljaju i na 
strani ponude i na strani potražnje. Financijsko tržište čine tržište kapitala (dugoročna sredstva) i tržište novca (kratkoročna sredstva). ${ }^{1}$

Financijsko se tržište, u osnovi, sastoji od tržišta novca i tržišta kapitala. Da li i kako financijsko tržište može funkcionirati u uvjetima isključivanja kamate iz finansijskih operacija? To je pitanje na koje mora odgovoriti islamska ekonomija koja ne priznaje kamatu kao dozvoljenu vrijednost.

\section{Finansijsko tržište $u$ islamskoj ekonomiji}

U savremenoj islamskoj ekonomiji posebno je značajan segment islamskih financija i njihovog tržišta, posebno iz razloga što islam najstrožije zabranjuje kamatu, tako da je to jedno od najznačajnijih pitanja savremene islamske ekonomske misli koja se u nekim principima krucijalno razlikuje od konvencionalne ekonomije. Jedna od preferiranih definicija islamske ekonomije, u čijem sastavu je i pitanje islamskog financijskog tržišta je ona koju daje dr. en-Nedžar:

„Islamska ekonomija je nauka koja se bavi prirodom ponašanja pojedinaca u njihovom odnosu prema aktivnostima vezanim za imovinska dobra u vidu privređivanja, finansiranja i usklađivanja ovih kategorija da budu u skladu $\mathrm{s}$ islamskim principima, intencijama Šerijata te njegovim općim pravilima i osnovama bez kolizije i sukoba sa šerijatskim tekstom i njegovim normama.“

Dakle, islamska ekonomija je zasebna, samostalna nauka, kako se definira po savremenim definicijima kao i bilo koja druga nauka. Islamska ekonomska misao, njeno učenje ili doktrina spada, faktički, u islamsku političku ekonomiju jer svoje osnove crpi iz tradicionalnih izvora islama (Kur'an i sunnet), mada njena praktična artikulacija sa vremenom i prostorom ima svoju evolutivnu praksu. Sistem islamske ekonomske misli je skup ekonomskih ideja povezanih sa ciljevima i sredstvima za njihovu realizaciju.

Cilj islamske ekonomije, kako navode neki autori je ispunjenje najveće moguće količine društvene sreće i prosperiteta za pojedinca i društvo a sredstva bi bila sadržana u sistemu islamskih ekonomskih kategorija i vrijednosti kao što su privatno vlasništvo, sloboda ograničena etičkim

\footnotetext{
${ }^{1}$ www.poslovni.hr/leksikon/financijsko-trziste-211 pristupljeno, 06 decembra 2017.
} 
vrijednostima i sl., ali i korištenje dostignuća do kojih je došla savremena nauka $\mathrm{u}$ materijalnom, idejnom, pravno-normativnom i svakom drugom pogledu. Islamska naučna ekonomija nije se razvila dok se nije praktično sproveo islam u domenu ekonomije. Tako se i islamska ekonomija sastoji, prema nekim teoretičarima islamske ekonomske misli, iz pravca (mezheb) i sistema (nizam). Pravac je u doktrinarnom smislu, a sistem u praktičnom. Stoga, u njenoj osnovi postoji konstanta koja je nepromjenljiva sa stabilnim principima za sva vremena i prostore, a ima i drugi dio varijabilne islamske ekonomske prakse koja se razlikuje u vremenu i prostoru i podložna je promjeni i prilagodbi.

\section{Pristup novčanom i tržištu kapitala u skladu sa islamskim principima}

Islamske banke su u znatno nepovoljnijem položaju od konvencionalnih u pogledu likvidnosti i profitabilnosti, dva divergentna cilja koji se jednako snažno postavljaju. Zbog činjenice da ne posluju sa kamatom ni kod ponude niti potražnje, islamske banke ne mogu učestvovati na konvencionalnom novčanom tržištu koje je uglavnom zasnovano na kamati i operacijama povezanim sa kamatom. Usljed nerazvijenosti islamski prihvatljivog novčanog tržišta, njegovih instrumenata $\mathrm{i}$ institucija, islamske banke su u potrebi da razvijaju finansijske instrumente zasnovane na principima Šerijata, a koji će olakšati postizanje spomenuta dva divergentna cilja.

Prema tome, a usljed odsustva globalnog islamskog novčanog tržišta, islamske banke se suočavaju sa problemom držanja deponirane gotovine koja ne donosi zaradu i koju zbog pravnog razloga ne mogu investirati u državne obveznice koje su, uglavnom, zasnovane na kamati. Uprkos tome malo se čini na praktičnom razvoju islamskog financijskog tržišta i njegovih instrumenata jer se teoretičari islamske ekonomije više usmjeravaju ka razvoju dugoročnih financijskih instrumenata tržišta kapitala, nego kratkoročnih financijskih instrumenata novčanog tržišta.

Zbog toga je potrebno za onoga ko želi dati doprinos pitanju islamskog financijskog tržišta da dobro prouči i elaborira kratkoročne vrijednosne papire konvencionalnog novčanog tržišta, da razumije njihove osnovne 
zajedničke karakteristike i da na koncu dâ njihovu ocjenu prihvatljivosti sa aspekta učenja islamske ekonomije.

Pitanja islamskog financijskog tržišta spadaju u domen varijabilne islamske ekonomske prakse koja se razlikuje u vremenu i prostoru, podložna je promjeni i prilagodbi, ali isto tako ta pitanja se moraju uskladiti sa konstantnim, nepromjenljivim principima islamske ekonomije kao što su:

Imetak je u Božijem vlasništvu, čovjek je samo zadužen s njim jer postoji velik broj tekstova koji eksplicitno potvrđuju ovaj princip:

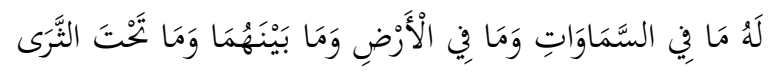

Njegovo je što je na nebesima, i na zemlji, i što je između njih, i što je pod zemljom! ${ }^{2}$

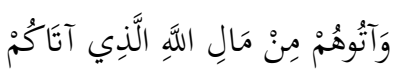

I dajte im nešto od imetka koji je Allah vama dao. ${ }^{3}$

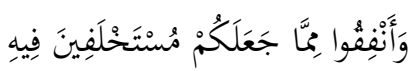

i udjeljujte iz onoga što vam je dao da naslijedite. ${ }^{4}$

Ostvarenje ograničene ekonomske slobode koja se očituje kroz zabranu kamate i drugih vidova nepravde i iskorištavanja čovjeka.

Ovaj princip se razumije iz kur'ansko-hadiskih tekstova koji zabranjuju kamatu, iskorištavanje, mito, potplaćivanje, monopol, prevaru, gomilanje, tvrdičluk i sl.

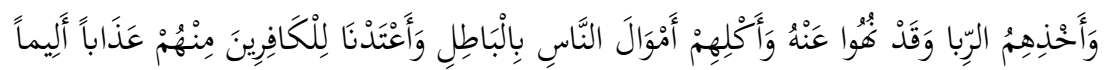

I zato što su kamatu uzimali, a bilo im je zabranjeno, i zato što su tuđe imetke na nedozvoljen način trošili. A za nevjernike među njima, Mi smo kaznu bolnu pripremili. ${ }^{5}$

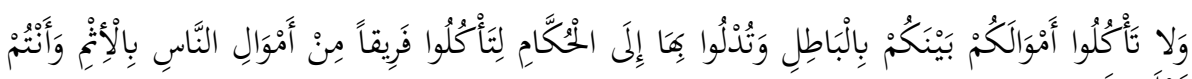

\footnotetext{
${ }^{2}$ Kur'an, Ta-ha, 6.

${ }^{3}$ Kur'an, En-Nur, 37.

${ }^{4}$ Kur'an, El-Hadid, 7.

${ }^{5}$ Kur'an, En-Nisa', 161.
} 
Ne jedite imovinu drugoga na nepošten način dajući dio sudijama kako biste na grješan način i svjesno dio imovine drugih ljudi pojeli. ${ }^{6}$

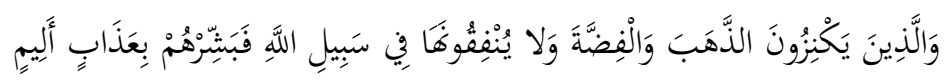

Onima koji zlato i srebro gomilaju i ne troše ga na Allahovu putu navijesti bolnu patnju. ${ }^{7}$

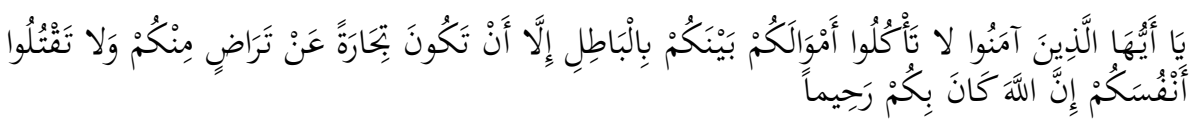

O vjernici, jedni od drugih na nedozvoljen način imanja ne prisvajajte, osim trgovinom uz obostrani pristanak, i sami sebe ne ubijajte! Allah je doista prema vama milostiv! ${ }^{8}$

Muslim je zabilježio predaju hadisa (1605) u kojoj se navodi da je Allahov Poslanik, a.s., rekao:

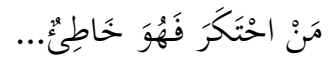

Griješi onaj ko se bavi monopolom.

Društvena pravda i ostvarenje ekonomske ravnoteže društva jer Kur'an propisuje obavezu zekata i ne dozvoljava da se kapital kreće samo među bogatima:

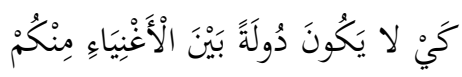

...da ne bi prelazio samo iz ruku u ruke bogataša vaših. ${ }^{9}$

Buharija je zabilježio hadis (1331.) da je Allahov Poslanik, a.s., kazao o obavezi zekjata:

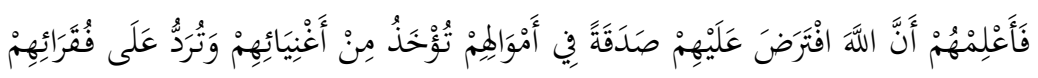

...Obavijesti ih da im je Uzvišeni Allah propisao zekat u njihovim imecima koji se uzme od bogatih i vrati njihovoj sirotinji

\footnotetext{
${ }^{6}$ Kur'an, El-Bekare, 188.

${ }^{7}$ Kur'an, Et-Tevbe, 34.

${ }^{8}$ Kur'an, En-Nisa', 29.

${ }^{9}$ Kur'an, El-Hašr, 7.
} 
Poštivanja ličnog vlasništva, bilo da se radi o mušku ili žensku, i egzemplarne sankcije koje se koriste za čuvanje vlasništva, kao što Kur'an proklamuje:

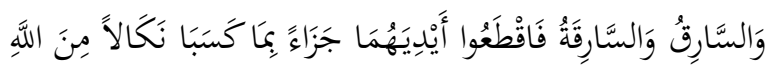

Kradljivcu i kradljivici odsijecite ruke njihove, neka im to bude kazna za ono što su učinili i opomena od Allaha! A Allah je silan i mudar. ${ }^{10}$

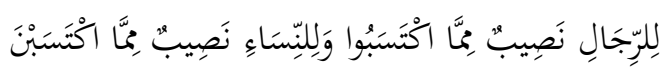

Muškarcima pripada udio za ono što zarade, a ženama udio za ono što one zarade! ${ }^{11}$

Onoga ko pogine štiteći svoj imetak Allahov Poslanik, a.s., proglasi šehidom.

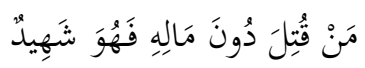

Ko pogine braneći svoj imetak postaje šehid ${ }^{12}$

Racionalno ekonomisanje sa materijalnim dobrima uz princip najekonomičnijeg finansiranja-ulaganja.

U Kur'anu se zabranjuje rasipništvo, škrtarenje ili neodgovorno ponašanje sa materijalnim vrijednostima:

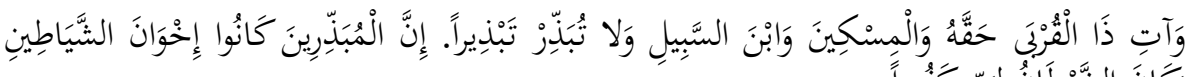

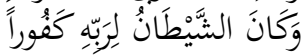

Daj bližnjemu svome pavo njegovo, i siromahu, i putniku-namjerniku, ali ne rasipaj mnogo, /26/ jer su rasipnici braća šejtanova, a šejtan je Gospodaru svome nezahvalan. ${ }^{13}$

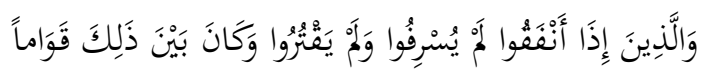

I oni koji, kad udjeljuju, ne rasipaju i ne škrtare, već se u tome drže sredine. ${ }^{14}$

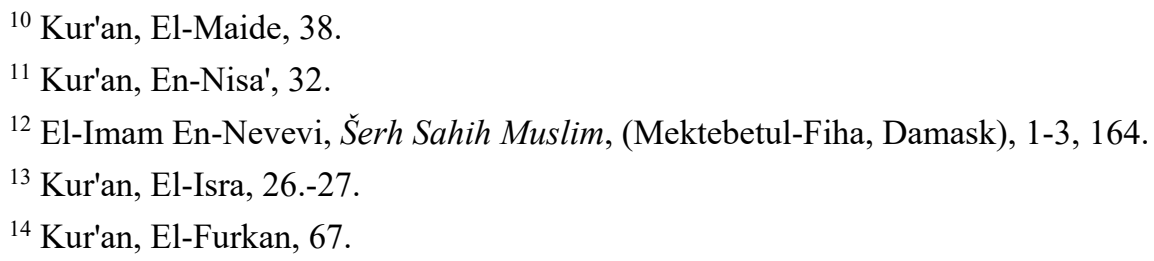




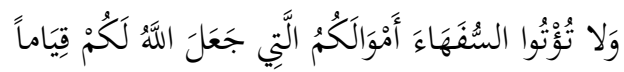

I maloumnicima ne dajite imetke koje vam je Allah povjerio na upravljanje! ${ }^{15}$ Pravedan balans u pravima pojedinca i društva te objava rata kamatarenju.

Kur'an izražava prijetnju onome ko upotrebljava imetak na nedozvoljen način i s kamatarenjem, eksplicitno objavljujući da je takva praksa objava rata Uzvišenom Allahu i Njegovom Poslaniku:

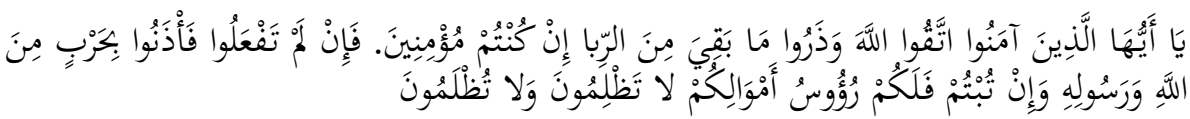

O vjernici, bojte se Allaha i ostavite što je preostalo od kamate, ako ste vjernici. /278/ Ako to ne učinite, navješćuje vam se rat od Allaha i Poslanika Njegova! A ako se pokajete, pripadaju vam glavnice imetaka vaših; nećete nepravdu učiniti niti će vama nepravda biti učinjena. ${ }^{16}$

Fikhsko pravilo utemeljeno na hasen hadisu, kojeg je zabilježio Ibn Madže i Darekutni kao i neki drugi hadiski autoriteti sa lancem prenosilaca te Malik u Muvettau ali sa prekinutom predajom od Allahovog Poslanika, a.s., glasi:

$$
\text { لَا ضَرَرَ وَلَا ضِرَارَ }
$$

Šteta se ne čini niti se štetom uzvraća.

Ovi generalni principi vezani za osnovne opće potrebe muslimanskog društva obavezujući su za primjenu u islamskoj ekonomiji i njenim pitanjima kao što je i pitanje islamskog finansijskog tržišta, u svakom vremenu i prostoru, bez obzira na ekonomski napredak, razvoj društva ili na njegovu zaostalost, a islamski ekonomski mislioci nazivaju ih terminom "el-mezhebul-iktisadil-islami" (islamski ekonomski pravac). ${ }^{17}$

Dio vezan za praktičnu primjenu islamske ekonomije koji sadrži načine, praktične planove i ekonomska rješenja do kojih su došli islamski mislioci analizirajući i proučavajući islamske principe i ekonomske

\footnotetext{
${ }^{15}$ Kur'an, En-Nisa', 5.

${ }^{16}$ Kur'an, El-Bekare, 278.-279.

17 El Fendžeri, Muhammed, Ševki, El Mezhebu -l -iktisadi fil-islami, (Mektebetu Ukaz, 1981.), 19-22.
} 
osnove spada $\mathrm{u}$ domen islamske ekonomske teorije "en-nazarijetuliktisadijjetul-islamijje" a u praktičnom smislu to je "en-nizamuliktisadil-islami" islamski ekonomski sistem. Ove teorije i ekonomski islamski sistemi su rezultat ekonomskog razmišljanja i rezonovanja. Oni su varijabilni, fleksibilni i često uslovljeni određenom situacijom, prilikama mjesta i vremena, a samim tim, podložni su varijabilnostima i promjenama. To se posebno primjećuje kod pitanja islamskog finansijskog tržišta.

Osnovne karakteristike islamskih finansijskih instrumenata

Spomenuli smo neke generalne principe islamske ekonomije koji se, naravo, odnose i na neke od osnovnih karakteristika islamskih finansijskih instrumenata. Profesor Hadžić te karakteristike sažima u sljedeće tačke:

predstavljaju dokaz o vlasništvu nad neto realnom imovinom 18 nabavljenom iz sredstava prikupljenih emisijom vrijednosnih papira; svom vlasniku daju pravo da učestvuje u raspodjeli profita ukoliko isti bude ostvaren realizacijom konkretnog projekta ili poslovanjem dioničkog društva;

njihova vrijednost ne može biti garantirana njihovom vlasniku od emitenta;

njihov vlasnik preuzima puni rizik i kao vlasnik kapitala učestvuje u pokriću eventualno nastalog gubitka;

ne mogu sadržavati pravo na unaprijed određeni garantirani profit, bilo u procentualnom ili nominalnom iznosu;

proces njihovog izdavanja i prometa mora biti u skladu sa principima Šerijata;

realizacija posla ili projekta vrši se u skladu sa principima mudaraba poslovnog odnosa;

poslovanje po mudaraba ugovoru mora se posebno evidentirati $i$ odvojiti od ostalog poslovanja mudariba. Ukoliko se radi o banci kao

\footnotetext{
18 "Neto realna imovina" predstavlja samo dio materijalnih ulaganja u projekat ili materijalnih sredstava aktive bilansa. Nematerijalna imovina ne može biti osnova za emisiju dionica.
} 
emitentu finansijskih instrumenata, onda za svaki projekt mora otvoriti zaseban račun sa čijim stanjem moraju biti upoznati svi zainteresirani, odnosno javnost ukoliko je u finansiranju učestvovao relativno veliki broj bančinih klijenata;utrživi su. ${ }^{19}$

Tržište vrijednosnih papira u mnogim muslimanskim zemljama još uvijek nije razvijeno. Međutim, u nekima (Pakistan, Iran, Malezija, Ujedinjeni Arapski Emirati, Jordan i Sudan) osnovane su berze na kojima se trguje islamskim finansijskim instrumentima. ${ }^{20}$

Princip halala (dozvoljeno) i harama (nedozvoljeno) u prometu vrijednostima

Općepoznato je da konvencionalna ekonomija ima za cilj ispunjenje i zadovoljenje svih čovjekovih materijalnih potreba bez ograničenja i bez obzira na duhovne vrijednosti, moral ili čak i materijalne posljedice po čovjeka.

Nasuprot toga, islamska ekonomija sve ljudske aktivnosti provjerava na konceptu halala i harama, kao što se razumije iz hadisa kojeg su zabilježili Buharija (1946.) i Muslim od en-Nu'man b. Bešira:

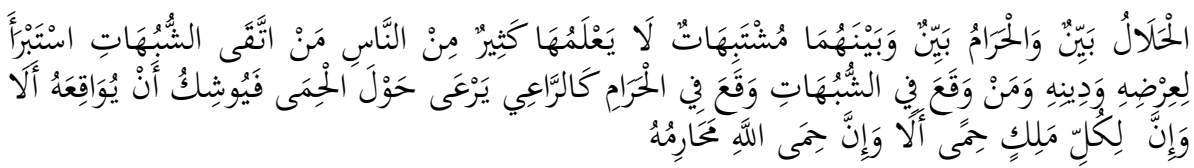

Halal je objašnjen i haram je objašnjen. Između njih su sumnjive stvari. Mnogi ljudi ih ne poznaju. Ko se čuva sumnjivih stvari, time ostaje neporočnog obraza i vjere. A ko upadne u sumnjivo, time je pao u haram kao čuvar koji napasa stado oko zabrana sa stalnom mogućnošću da upadne u njeg. Svaki vladar ima svoje zabrane, a Allahove zabrane su njegovi harami.

Iz ove hadiske norme razumije se da islamska ekonomija vodi računa o ispunjenju i zadovoljenju duhovnih ili materijalnih potreba ali samo onih koje su dozvoljene (halal). Idući tom logikom Uzvišeni je

${ }^{19}$ M. Štulanović i F. Hadžić, Osnovi islamske ekonomije i finansija,(CPA, Tojšić, Bihać, 2007.), 278-279.

${ }^{20} \mathrm{O}$ iskustvima praktične primjene islamskih finansijskih instrumenata vidi: Hadžić, Fikret, Islamsko bankarstvo i ekonomski razvoj, Ekonomski fakultet u Sarajevu, Sarajevo, 2005. 
preskriptivnom aksiologijom odobrio (halal) upotrebu i korištenje lijepog, univerzalnog dobra (tajjibat) od hrane, odjeće, stana, imetka i drugih vrijednosti, i suprotno od toga, zabranio je (haram), tj. upotrebu i korištenje ružnog, univerzalnog zla i nevaljalština (habais) kako bi priskrbio korist za čovjeka i društvo, a otklonio štetu od njih.

Uzvišeni kaže:

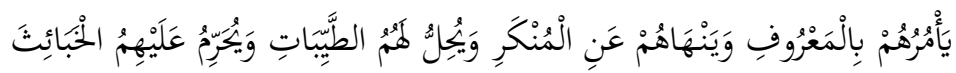

...Koji će od njih tražiti da čine dobra djela, a od odvratnih odvraćati ih, koji će im lijepa jela dozvoliti, a ružna im zabraniti. ${ }^{21}$

\section{Financijski instrumenti islamskog novčanog tržišta}

Neki od konvencionalnih instrumenata u svojoj sadašnjoj i osnovnoj formi su u potpunosti nepodesni za adaptaciju na islamski prihvatljiv način poslovanja, dok bi se neki drugi, uz neophodna prilagođavanja, mogli učiniti kompatibilnim principima Šerijata, a time i koristiti na islamskom novčanom tržištu. U projekat mogućih adaptacija mogli bi se uključiti sukladno nekim teoretičarima islamske ekonomije: utrživi depozitni certifikati, komercijalni zapisi, bankarski i komercijalni akcepti, aranžmani o rekupovini i državni blagajnički zapisi, dok bi ostali bili nepodesni za prilagođavanje. Međutim, prema nekim islamskim ekonomistima valutni svop (swaps) kao financijski instrument čijom se upotrebom transaktori osiguravaju od rizika promjene deviznog kursa predstavljaju, po Šerijatu, dozvoljeni financijski instrument konvencionalnog novčanog tržišta. ${ }^{22}$

Što se tiče islamskih modela finansiranja koji bi se mogli upotrijebiti, prof. Hadžić navodi da Ahmed Osman Babikir ${ }^{23}$ u svojoj studiji daje prijedlog kratkoročnih islamskih finansijskih instrumenata koji su zasnovani na murabahi, mušaraki, mudarabi, baj'i al-salam, istisna'u i

\footnotetext{
${ }^{21}$ Kur'an, El-E'araf, 157.

${ }^{22}$ Prof. Hadžić za ovo navodi sljedeći izvor: Siddiqi, Moin, Banking on Shari'ah principles, Middle East, Jul/Aug, 2002., Issue 324. Vidi: M. Štulanović iF. Hadžić, Osnoviislamskeekonomijeifinansija,( CPA, Tojšić, Bihać, 2007.), 263.

${ }^{23}$ Detaljnijevidi: Ahmed, Osman, Babikir, Islamic Financial Instruments to manage short-term excess liquidity, Islamic Development Bank, Islamic Research and Training Institute, Jeddah, S.A, 1997., pp 79-92.
} 
idžari modelima finansiranja a koji bi se mogli koristiti u operacijama na islamskom novčanom tržištu ${ }^{24}$

\section{Primjer islamskog novčanog tržišta u muslimanskom svijetu}

Islamsko novčano tržište, uglavnom, funkcionira na nacionalnom nivou. Takav je primjer Malezije koja je organizirala islamsko novčano tržište tako što je na inicijativu Centralne banke Malezije (Bank Negara) u januaru 1994. godine osnovano islamsko međubankarsko novčano tržište (Islamic Interbank Money Market - IIMM) koje pokriva tri aspekta:

1) međubankarsko investiranje,

2) međubankarsku trgovinu islamskim financijskim instrumentima $i$

3) međubankarski (ček i akreditiv) kliring sistem.

Centralna banka Malezije ima i proaktivnu ulogu u kreiranju različitih vrsta financijskih instrumenata islamskog novčanog tržišta. Svih 38 finansijskih institucija ${ }^{25}$ koje u svom poslovanju primjenjuju islamske principe uključene su u islamsko novčano tržište, čime one, nakon perioda "apstinencije" ili minimalnog angažmana, danas igraju značajnu ulogu na ukupnom novčanom tržištu Malezije ${ }^{26}$

Sa aspekta principa islamske ekonomije i izvora islama nije sporno ni postojanje tržišta kapitala niti aktivnosti na tom tržištu uz uvjet da one nisu u suprotnosti sa Šerijatom inače bi se radilo o nedozvoljenim ili ilegalnim aktivnostima.

\footnotetext{
${ }^{24}$ M. Štulanović iF. Hadžić, Osnoviislamskeekonomijeifinansija,( CPA, Tojšić, Bihać, 2007.), 263.

${ }^{25}$ Njih su krajem 2001. godine činile: 2 islamske banke, 14 komercijalnih banaka koje nude islamske finansijske usluge, 10 finansijskih kompanija, 5 trgovačkih banaka i 7 diskontnih kuća. Bank Negara: Annual Report 2001, The Financial Sector, p. 148.

${ }^{26}$ M. Štulanović i F. Hadžić, Osnovi islamske ekonomije i finansija,(CPA, Tojšić, Bihać, 2007.), 264.
} 


\section{Neprihvatljivi financijski instrumenti u islamskoj ekonomiji}

Profesor Hadžić ${ }^{27}$ navodi da se na novčanom tržištu zapadnih zemalja koriste različiti kratkoročni financijski instrumenti:

- državne obveznice (tresory bonds);

- državni blagajnički zapisi (tresory bills - TBs);

- blagajnički zapisi centralne banke (central bank's papers CBPs);

- bankarski akcepti (banker's acceptance - BA);

- utrživi depozitni certifikati (negotiable certificates of depozit NCDs);

- komercijalni zapisi (commercial papers - CPs);

- komercijalni akcepti (commercial acceptance - CA);

- aranžmani o rekupovini obveznica (repurchase agreements Repos);

- $\quad$ aranžirani ili SVIP depoziti (sweep accounts);

- depozitni računi novčanog tržišta (money-market deposit accounts);

- overdraft računi (sa dopuštenim prekoračenjem) (overdraft checking account);

- NOW aranžmani (negotiable order of withdrawal);

- roll-over krediti (oročeni depoziti ili krediti sa automatskim produženjem) (roll-over credit's);

- hedžing ili transakcije izbjegavanja rizika kod jedne poslovne operacije preduzimanjem druge (hedging transactions):

- terminske transakcije (forwards);

- opcije (options);

- $\quad$ svopovi (swaps);

${ }^{27}$ Ibid., 261-262. 
- fjučersi (futures);

- operacije na eurodolar i eurobond tržištu.

Zatim dr. Hadžić navodi o ovim kratkoročnim vrijednosnim papirima i aranžmanima da se koriste samo na određenim novčanim tržištima (npr. gilt-edged bonds na Londonskom novčanom tržištu). Neki od navedenih vrsta vrijednosnih papira predstavljaju tzv. finansijske inovacije koje su nastale u novije vrijeme u funkciji minimalizacije $\mathrm{i}$ apsorbiranja rizika.

Potom dr. Hadžić daje pravno-šerijatski sud o njima kazavši da njihova osnovna zajednička karakteristika jeste ta da su svi posredno ili neposredno zasnovani na kamati i operacijama koje uključuju kamatu, što je sa aspekta Šerijata neprihvatljivo. Samim tim možemo i bez dodatne argumentacije zaključiti da su navedeni kratkoročni vrijednosni papiri konvencionalnog novčanog tržišta neprihvatljivi i nedozvoljeni, kako za operacije islamskih financijskih institucija na konvencionalnim novčanim tržištima, tako i za njihovo korištenje na islamskim novčanim tržištima. ${ }^{28}$

A što se tiče drugih islamski neprihvatljivih financijskih instrumenata, prof. Hadžić ${ }^{29}$ navodi da obveznica, kao važan instrument konvencionalnog finansijskog tržišta, tijesno je povezana sa kamatom tako da su njihovo izdavanje, trgovina i promet zabranjeni sa aspekta Šerijata. ${ }^{30}$ Iako mnogi islamski financijski instrumenti u svom nazivu

28 Prof. Hadžić to argumentuje slijedećim: - Pojedinačnu analizu osnovnih kratkoročnih vrijednosnih papira konvencionalnog novčanog tržišta vidi: Ahmed, Osman, Babikir, Islamic Financial Instruments to manage short-term excess liquidity, Islamic Development Bank, Islamic Research and Training Institute, Jeddah, S.A, 1997., pp. 21-41.

${ }^{29}$ Ibid., 267.

${ }^{30}$ Prof. Hadžić to argumentuje slijedećim: - Isto je jasno potvrđeno rezolucijom Islamic Fiqh Academy. Vidi: Yousif, Al-Yousif, Khalifa, Financial Markets: An Islamic Perspective, a lecture prepared for $8^{\text {th }}$ Intensive Orientation Course: Islamic Economics, Banking \& Finance, Seminar Proceedings, Markfield Conference Centre, Leicestershire, UK, 1999., p. 6.; Također vidi: Hassan, Hussein, Hamid, Flexibility of Shari'ah Principles of Finance and Resource Mobilization needs of Guvermnents, u Ahmad, Ausaf i Khan, Tariqullah, Islamic Financial Instruments for Public Sector Resource Mobilization, Islamic Development Bank, Islamic Research and Training Institute, Jeddah, S.A, 1997., p. 41. 
sadrže riječ "obveznica" (bonds), treba naglasiti da oni u biti ne predstavljaju obveznice u konvencionalnom (navedenom) značenju tog pojma. One nemaju karakteristike klasičnih obveznica, a njihovo suštinsko određenje bliže je pojmu "dionice" nego obveznice. To su tzv. "razvojne obveznice" kod kojih je stopa povrata vezana za cash flows projekta koji se njima financira. U ovom slučaju, obično se radi o finansiranju većih, infrastrukturnih projekata. ${ }^{31}$

Međutim, obične dionice, ukoliko potječu od halal društava ili kompanija koje se bave dozvoljenim ili halal poslovnim aktivnostima, ukoliko su svoju imovinu stekle na halal način, posluju na halal način, te ako se promet njihovih dionica vrši na jedan od dozvoljenih načina trgovine, onda se može zaključiti da su obične dionice i njihovo tržište prihvatljivo je sa aspekta islamske ekonomije.

Preferencijalne ili prioritetne dionice predstavljaju tipične hibridne vrijednosne papire jer sadrže karakteristike kako dionica, tako i obveznica i upoređujući ih sa principima islamske ekonomije može se zaključiti da preferencijalne dionice predstavljaju neprihvatljiv financijski instrument sa aspekta Šerijata. Isto tako varanti, opcije i fjučersi nisu u skladu sa principima isl. ekonomije.

\section{Islamski financijski instrumenti}

Islamski financijski instrumenti koji se mogu koristiti za prikupljanje i mobilizaciju štednje uglavnom se naslanjaju na dva osnovna modela financiranja (mušareka i mudareba), dok se, u novije vrijeme, razvijaju i novi modeli koji su zasnovani na nekim drugim osnovama financiranja, ili na njihovoj međusobnoj kombinaciji kao što su selem, istisna', idžara, qard hasen i drugi koji po svojim karakteristikama slijede osnovne principe navedenih modela finansiranja. Sinonim u pravnim mezhebima Šerijata za mudarebu je qirad, a za mudariba je muqarid, ${ }^{32}$ tako da se u literaturi često susreće termin qirad bonds.

\footnotetext{
31 Siddiqi, Moin, Banking on Shari'ah principles, Middle East, Jul/Aug, 2002., Issue 324.

${ }^{32}$ Malikijska i šafijska pravna škola preferiraju termin qirad i muqarid, dok hanefijska i hanbelijska preferiraju termine mudaraeba i mudarib.
} 
Sakk pl. sukuk je termin koji se upotrebljava u kontekstu finansijskih inovacija u procesu tzv. sekuritizacije aktive. ${ }^{33}$ To je pojam koji islamske banke koriste kada je u pitanju sekuritizacija a odnosi se na vrijednosni papir koji je uvijek ,vezan” za određenu aktivu (realnu imovinu), obezbjeđuje određeni prihod, utrživ je i u skladu je Šerijatom.

Financijski instrument koji predstavlja partnerstvo, kao što je mušareka, može biti predmetom sekuritizacije. Za validno trgovanje mušareka certifikatima nužno je da nelikvidna sredstva čine više od polovine ukupnog portfolija mušareke. ${ }^{34}$ Isto tako i idžara, kao mehanizam finansiranja na bazi najma, može biti pogodna za sekuritizaciju. Ovim imalac sukuka stiče pravo vlasništva nad iznajmljenim sredstvom u omjeru njegovog učešća u vrijednosti, te mu, po tom osnovu, pripada $i$ pravo proporcionalnog udjela $u$ renti. Možemo razlikovati više vrsta sukuk vrijednosnih papira (mudareba sukuk, mušareka sukuk, idžara sukuk, selem sukuk i druge). ${ }^{35}$

\section{Zaključci}

Islamska ekonomija sve ljudske aktivnosti provjerava na konceptu halala i harama, pa tako i financijska tržišta.

U konvencionalnoj ekonomiji, financijska ili tržišta novca označavaju skup institucija i transakcija gdje se susreću kupci i prodavači, odnosno to su mjesta, na kojima se odvija trgovina kapitalom koja predstavlja osobe, instrumente, tehnike i tokove te omogućava razmjenu novčanih viškova i manjkova, tj. novca, kapitala i deviza. Razvijena financijska tržišta obiluju financijskim instrumentima, raznovrsnim financijskim

\footnotetext{
33 Sekuritizacija se definira kao posao pretvaranja nelikvidne u likvidnu financijsku imovinu prikojima nelikividna financijska imovina (npr. portfelj kredita) najčešće služi kao osiguranje zaizdanje vrijednosnih papira. Odnosno, sekuritizacija (engl. securitization) predstavlja nove tehnike financiranja u kojima se klasični oblici potraživanja pretvaraju u nove odnose koje sada predstavljaju vrijednosni papiri. Vidi: www.academia.edu/12210717/Sekuritizacija_potraživanja, Pristupljeno: 08, decembar, 2017.

${ }^{34}$ Usmani, Ibid., p. 52.

35 Tariq, Ali Arslan, Managing Financial Risks of Sukuk Structures, Loughborough University, UK, Master Dissertation, September 2004. p. 20; O pojedinim primjerima idžara sukuka, takođe vidjeti na str. 31-40.
} 
institucijama, složenim financijskim tehnikama i brojnim financijskim tokovima pa se dijele na tržište novca i kratkoročnih vrijednosnih papira, tržište kapitala i devizno tržište.

Pitanja islamskog financijskog tržišta spadaju u domen varijabilne islamske ekonomske prakse koja se razlikuje u vremenu i prostoru, podložna je promjeni i prilagodbi. Islamska financijska tržišta se moraju uskladiti sa konstantnim, nepromjenljivim principima islamske ekonomije.

Mnogi od instrumenata finansijskog tržišta koji se koriste $u$ konvencionalnoj ekonomiji, u svojoj sadašnjoj i osnovnoj formi, u potpunosti su nepodesni za adaptaciju na islamski prihvatljiv način poslovanja, dok se neki drugi, uz neophodna prilagođavanja, mogu učiniti kompatibilnim sa principima Šerijata, a onda i legitimno koristiti na islamskom novčanom tržištu. Sukladno nekim teoretičarima islamske ekonomije u projekat mogućih adaptacija mogli bi se uključiti: utrživi depozitni certifikati, komercijalni zapisi, bankarski i komercijalni akcepti, aranžmani o rekupovini i državni blagajnički zapisi.

Neki teoretičari islamske ekonomije, daju prijedlog kratkoročnih islamskih finansijskih instrumenata koji su zasnovani na murabehi, mušareki, mudarebi, baj'i al-selem, istisna'u i idžari modelima finansiranja.

Nije sporno postojanje tržišta kapitala niti aktivnosti na tom tržištu sa aspekta principa islamske ekonomije i izvora islama uz uvjet da te aktivnosti nisu u suprotnosti sa Šerijatom.

\section{Literatura}

1. Abdullah Et-Turejki, Islamska ekonomija, usus ve mebadi' ve ehdaf, (Rijad, muessesetul-Džurejsi, deseto izdanje, 2005),

2. Ahmed, Osman, Babikir, Islamic Financial Instruments to manage short-term excess liquidity, (Islamic Development Bank, Islamic Research and Training Institute, Jeddah, S.A, 1997.),

3. Dhareer, Al-, Siddiq, Mohammad, Al-Ameen, Al-Gharar in contracts and its effects on contemporary transactions, (Islamic Development Bank, Islamic Research and Training Institute, Jeddah, S.A, 1997.), 
4. Dr. Muslih Abdul-Hajj En-Nedžar, En-Nizamul-mali vel-iktisadi filislam, (Mektebetur-Rušd, Riyadh, 2005.),

5. Dr. Muhammed Revas Kal'atdži, dr. Hamid Sadik Kanibi, Mu'džemu lugati-l-fukaha'i, 'arebi-inklizi (Darun-nefais, 1985.),

6. Dr. Muslih Abdul-Hajj En-Nedžar, En-Nizamul-mali vel-iktisadi filislam, (Mektebetur-Rušd, Riyadh, 2005.), 23.

7. Dr. Obren Blagojević, Ekonomske doktrine, (Privredni pregled, treće izdanje, Beograd 1979.),

8. Dr. Vehbe ez-Zuhajli, El-Fikhu-1-islamijju ve edilletuh (Daru-1-fikr, 1986.),

9. Dr. Vehbe ez-Zuhajli, Usulu-1-fikhi-1-islami (Daru-1-fikr, 1986.),

10. El Fendžeri, Muhammed, Ševki, El Mezhebu -1 -iktisadi fil- islami, (Mektebetu Ukaz, 1981.),

11. El-Imam En-Nevevi, Šerh Sahih Muslim, (Mektebetul-Fiha, Damask),

12. Fikret Hadžić, Islamsko bankarstvo i ekonomski razvoj, (Ekonomski fakultet u Sarajevu, 2005.),

13. Yousif, Al-Yousif, Khalifa, Financial Markets: An Islamic Perspective, a lecture prepared for 8th Intensive Orientation Course: Islamic Economics, Banking \& Finance, Seminar Proceedings, Markfield Conference Centre, Leicestershire, UK, 1999.,

14. M. Štulanović i F. Hadžić, Osnovi islamske ekonomije i finansija,( CPA, Tojšić, Bihać, 2007.),

15. Mustafa Ahmed ez-Zerka, El-Medhalu-1-fikhi-1-'amm, (Daru-1-fikr, 1968.),

16. P.Rose, Menadžment komercijalnih banaka, MATE, Zagreb, 2003.,

17. Siddiqi, Moin, Banking on Shari'ah principles, Middle East, Jul/Aug, 2002.,

18. Tariq, Ali Arslan, Managing Financial Risks of Sukuk Structures, Loughborough University, UK, Master Dissertation, September 2004.

\section{Internet}

19. https://hr.wikipedia.org/wiki/Financijska tržišta, pristupljeno, 06 decembra 2017.

20. www.poslovni.hr/leksikon/financijsko-trziste-211 pristupljeno, 06 decembra 2017.

21. www.academia.edu/12210717/Sekuritizacija_potraživanja 


\section{Mudzahid Stulanovic, BA \\ University of Bihać \\ Faculty of Islamic Pedagogy \\ mudzastulanovic@gmail.com}

Original scientific paper

\section{THE PRINCIPLES AND INSTRUMENTS OF THE ISLAMIC FINANCIAL MARKET}

\section{Summary}

The financial market (Finanzmarkt) or the money markets in a conventional economy represents a set of institutions and transactions where buyers and sellers meet and where trading of capital takes place, that is, these are places, persons, instruments, techniques and flows that allow for the exchange of cash surpluses and shortages, i.e. money, capital and foreign exchange. Undeveloped financial markets are reduced to deposits, loans and banks, and developed markets are abound with financial instruments, various financial institutions, complex financial techniques and numerous financial flows, so they are divided into the money market and short-term securities market, the capital market and the foreign exchange market.

A current and important question is raised as to whether and how such a defined financial market can function under the conditions of excluding of interest from financial operations?

This is a question that must be answered by the theorists of the Islamic economy which does not recognize interest as a permissible value. Issues of the Islamic financial market are in the domain of variable Islamic economic practice that differs in time and space, and is a subject to change and adjustment, but they must also be aligned with the constant, immutable principles of the Islamic economy. Some theorists of the Islamic economy, such as Ahmad Osman Babikir himself, propose short-term Islamic financial instruments based on Murabaha, Musharaka, Mudaraba, Bai Salam, Istisna and Ijara financing models, which could be used in operations in the Islamic money market.

Key words: Islamic economy, Islamic financial market, conventional economy, money market, capital market, financial instruments, Islamic financial instruments. 


$$
\begin{aligned}
& \text { المعيد مجاهد شتولانوفيتش } \\
& \text { جامعة بيهاتش } \\
& \text { كلية التربية الإسلامية }
\end{aligned}
$$

mudzastulanovic@gmail.com

مبادئ السوق المالي الإسلامي وآلياته

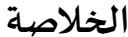

السوق المالي أو أسواق المال في الاقتصياد التقليدي يمثل مجموعة من المؤسسات

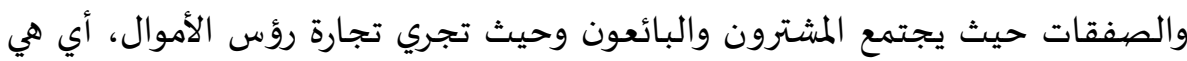

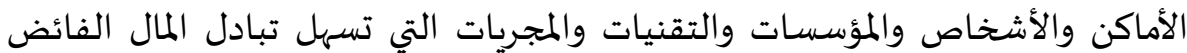

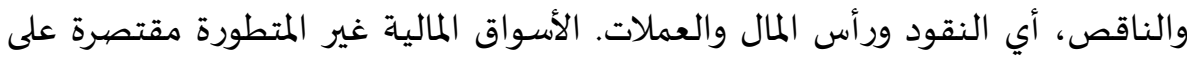
الودائع، القروض والبنوك، بينما المتطورة تكثر فيها الآليات المالية والمؤسسات الماتلمالية

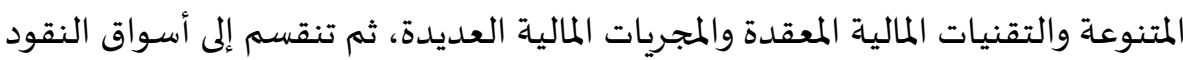

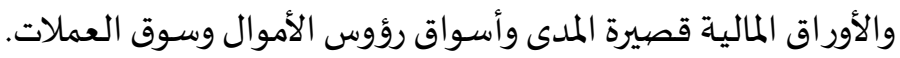
هناك سؤال مهم وراهن يطرح نفسـه وهو كيف لمثل هذا سوق المال الذي بيناه يمكنه

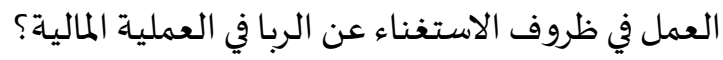

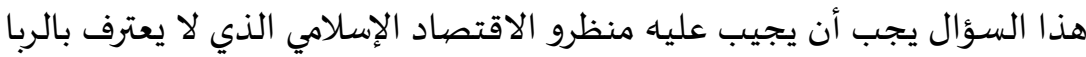
باعتبارها القيمة المسوح بها. مسائل السوق المال الإسلامي تدخل في نطاق الاقتصياد

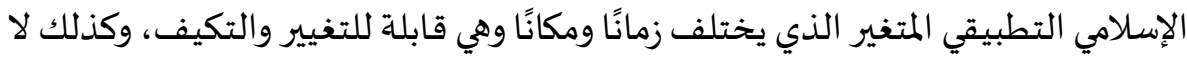
بد من التوافق بينها وبين مبادئ الاقتصاد الإسلامي الثابتة وغير المتغيرة. بعض منظري الاقتصاد الإسلامي، مثل أحمد عثمان بابكر يقدم مقترح الآليات

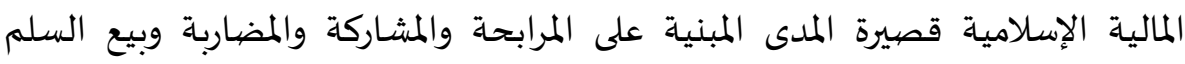
والاستصناع والإجارة وغيرها من أسـاليب التمويل التي يمكن استخدامها في العمليات في الميك سوق المال الإسلامي. الكلمات الرئيسـة: الاقتصاد الإسلامي، السوق المالي الإسلامي، الاقتصاد التقليدي، سوق النقود، سوق رأس المال، آليات مالية، آليات مالية إسلامية. 